\title{
A new rapidly growing mycobacterial species, Mycobacterium murale sp. nov., isolated from the indoor walls of a children's day care centre
}

\author{
R. Vuorio, ${ }^{1}$ M. A. Andersson, ${ }^{1}$ F. A. Rainey, ${ }^{2}$ R. M. Kroppenstedt, ${ }^{3}$ \\ P. Kämpfer, ${ }^{4}$ H.-J. Busse, ${ }^{1} \dagger$ M. Viljanen ${ }^{5}$ and M. Salkinoja-Salonen ${ }^{1}$
}

Author for correspondence: R. Vuorio. Tel: +3589708 59333. Fax: +358970859322. e-mail: Riitta.Vuorio@Helsinki.fi

\footnotetext{
1 Department of Applied Chemistry and Microbiology, PO Box 56 (Biocentre), 00014 University of Helsinki, Finland

2 Department of Microbiology, 508 Life Sciences Building, Louisiana State University, Baton Rouge, LA 70803 . USA

${ }^{3}$ DSMZ-Deutsche Sammlung von Mikroorganismen und Zellkulturen, D-38124 Braunschweig, Germany

4 Institut fuer Angewandte Mikrobiologie, JustusLiebig Universităt, Senckenbergstr. 3, D-35390 Giessen, Germany

5 National Public Health Institute, Department in Turku, Kiinamyllynkatu 13, FIN-20520 Turku, Finland
}

\begin{abstract}
Scotochromogenic mycobacterial isolates from water-damaged parts of indoor building materials of a children's day care centre represented a phenetically and genetically distinct group of strains. A 165 rDNA dendrogram (1243 bp) showed that the closest species to the new strain MA112/96' ${ }^{\mathrm{T}}$ was Mycobacterium abscessus. Phylogenetic and phenetic analyses (100 characteristics) grouped the new isolates with $M$. abscessus, Mycobacterium vaccae, Mycobacterium aurum and Mycobacterium austroafricanum.

Ribotyping with Pvull restriction distinguished the 5 isolates from the other 12 most closely related species by the major bands at 6.5-7 kb and 13-15 kb. The cell morphology of the new isolates was typical of mycobacteria, electron microscopy revealed a triple-layered cell wall with an irregular electron-dense outer layer. They grew at $10-37^{\circ} \mathrm{C}$, with no growth at $45^{\circ} \mathrm{C}$ in $5 \mathrm{~d}$. The gene encoding the secreted 32 kDa protein, specific to mycobacteria, was detected by PCR. The main whole-cell fatty acids were characterized by high tuberculostearic acid $10 \mathrm{Me}-\mathrm{C}_{18: 0}\left(17 \%\right.$ at $\left.28{ }^{\circ} \mathrm{C}\right)$, which increased with increasing growth temperature $\left(22 \%\right.$ at $\left.37{ }^{\circ} \mathrm{C}\right)$. The other main fatty acids were $C_{18: 1}$ cis9 and $C_{16: 0}\left(21-20 \%\right.$ each), followed by, $C_{17: 1}$ cis9 (14\%), $C_{16: 1}$ cis10 (8\%) and also a high amount of $C_{20}$ alcohol $(9 \%)$. $\alpha$-Mycolic acids, keto-mycolates and wax esters were present $\left(\mathrm{C}_{60}-\mathrm{C}_{90}\right), \mathrm{MK}-9\left(\mathrm{H}_{2}\right)(90 \%)$ and $\mathrm{MK}-8\left(\mathrm{H}_{2}\right)$ were the main menaquinones. The cellular phospholipids were phosphatidylethanolamine, phosphatidylinositol, phosphatidyl inositolmannosides and diphosphatidylglycerol. Polyamine content was low. G+C content was $72.9 \mathrm{~mol} \%$. The new isolates are proposed as a new species, Mycobacterium murale sp. nov. The type strain is MA112/96' (= DSM 44340').
\end{abstract}

Keywords: indoor contaminant, ribotyping, 16S rDNA, Mycobacterium abscessus, Mycobacterium komossense

\section{INTRODUCTION}

Non-tuberculous mycobacteria are widespread in the environment, ranging from harmless inhabitants of water and soil to species pathogenic to man and

\footnotetext{
†Present address: Institut fuer Bakteriologie und Tierhygiene, Veterinărmedizinische Universităt, Josef Baumann Gasse 1, A-1210 Wien, Austria.

Abbreviations: DPG, diphosphatidylglycerol; $P E$, phosphatidylethanolamine; PI, phosphatidylinositol; PIM, phosphatidyl inositolmannosides.

The GenBank accession number for the 165 rDNA sequence of strain MA112/96' (= DSM 44340') is Y08857.
}

animals (Guay, 1996). We recently reported rapidly growing mycobacteria as a major bacterial colonizer of water-damaged sites in the indoor walls of a children's day care centre (Andersson et al., 1997). During the renovation of this moisture-damaged building, $10^{6}$ c.f.u. of mycobacteria, $10^{7}$ c.f.u. of Gram-negative bacteria and toxin-producing fungi besides other microbes were found $g^{-1}$ of the water-damaged gypsum board liner. There are few reports of mycobacteria in dwellings. Dustborne mycobacteria have been reported in tuberculous patients' rooms (Tsukamura et al., 1974), in the indoor air of houses (Reznikov et al., 1971; Flannigan, 1995) and from the tap water in 
hospitals and homes (Peters et al., 1995). Mycobacteria are excellent survivors, living cells were found more than 2 months after inoculation to dry conditions (Hirai, 1991).

The present study is a polyphasic characterization of scotochromogenic mycobacterial isolates from waterdamaged building material. Comparison of the almost full 16S rDNA sequences clustered the new isolates closest to Mycobacterium abscessus NCTC $13031^{\mathrm{T}}$. Chemotaxonomic characters, phylogenetic analysis and ribotyping as a new tool for characterizing mycobacteria, as well as morphological and biochemical tests showed that these strains represent a new mycobacterial species, to which the name $\mathrm{Myco}$ bacterium murale sp. nov. is proposed.

\section{METHODS}

Bacterial strains. The bacterial strains used in this study are described in Table 1. Five mycobacterial isolates were isolated from water-damaged building material of a children's day care centre as described previously (Andersson et al., 1995, 1997). The isolates MA112/96 ${ }^{\mathrm{T}}$, MA113/96, MA142/96 and MA168/96 were isolated at $22{ }^{\circ} \mathrm{C}$ and the MA166/96 at $16^{\circ} \mathrm{C}$ on Tryptone soy agar plates (Difco).

Characterization of strains. Temperature tolerance of growth was tested on PYE agar plates (0.3\% peptone from casein, $0.3 \%$ yeast extract, $1 \cdot 5 \%$ agar, $\mathrm{pH}=7 \cdot 2$ ) at $6,10,28,45$ and $52{ }^{\circ} \mathrm{C}, \Delta \mathrm{T} \pm 0 \cdot 2^{\circ} \mathrm{C}$. For the measurement of the optimal growth temperature TSB liquid medium (tryptone soy broth) in microtitre plates and a shaking incubator
(Bioscreen) $\left(22,30\right.$ and $\left.37^{\circ} \mathrm{C} ; \Delta \mathrm{T} \pm 0.5^{\circ} \mathrm{C}\right)$ were used, with inoculum of $1: 10,1: 100$ or $1: 1000$ of a Klett $=120$ suspension (Klett photometer, red filter), incubated for $4 \mathrm{~d}$. Pigment production, photoreactivity and colony morphology were observed by light microscopy.

Microscopy. Acid-alcohol-fastness and presence of spores were tested as described previously (Murray et al., 1994). For electron microscopy the cells were grown on tryptic soy agar for $7 \mathrm{~d}$ at $28^{\circ} \mathrm{C}$. Thin sections were prepared as described previously (Andersson et al., 1995).

Identification by PCR. PCR amplification of a segment of the gene encoding the $32 \mathrm{kDa}$ mycobacterial protein was performed as described previously (Soini et al., 1992).

Antimicrobial sensitivity. Sensitivities of the new isolates to amikacin, azithromycin, chloramphenicol, ciprofloxacin, clarithromycin, doxycyclin, penicillin G, ceftazidime and vancomycin were tested with E-test strips (AB Biodisk). Sensitivities to isoniazid $\left(1 \mathrm{mg} \mathrm{l}^{-1}\right)$, rifampin $\left(5 \mathrm{mg} \mathrm{l}^{-1}\right)$, streptomycin $\left(10 \mathrm{mg} \mathrm{l}^{-1}\right)$ and ethambutol $\left(2 \mathrm{mg} \mathrm{l}^{-1}\right)$ were tested by the disk-elutriation method described by Wayne \& Krasnow (1966).

Analysis of fatty acids, polar lipids, cell wall, quinones, mycolic acids and $\mathbf{G}+\mathbf{C}$ content. For whole-cell fatty acids and the other chemotaxonomic analyses, the strains were grown on Middlebrook 7H10 agar (Difco) enriched with Middlebrook OADC or on PYE agar plates. Fatty acid methyl esters were prepared after $4 \mathrm{~d}$ incubation at $28^{\circ} \mathrm{C}$ and analysed as previously (Briglia et al., 1996). The chemotaxonomic analyses of polar lipids by using authentic phosphatidylethanolamine (PE), phosphatidylinositol (PI) and diphosphatidylglycerol (DPG) (Sigma) as references; sugars and amino acids of whole-cell hydrolysates, isoprenoid quinones, mycolic acids and determination of the

Table 1. Mycobacterial isolates and reference strains used in this study

NCTC, National Collection of Type Cultures, London, UK; DSMZ, German Collection of

Microorganisms and Cell Cultures, Braunschweig, Germany.

\begin{tabular}{|c|c|c|}
\hline Name & Number & Obtained from: \\
\hline New isolate & MA112/96 & This study \\
\hline New isolate & MA113/96 & This study \\
\hline New isolate & MA142/96 & This study \\
\hline New isolate & MA166/96 & This study \\
\hline New isolate & MA168/96 & This study \\
\hline M. abscessus & NCTC $13031^{\mathrm{T} *}$ & NCTC \\
\hline M. abscessus & NCTC 10882 & NCTC \\
\hline M. aichiense & DSM $44147^{T}$ & DSMZ \\
\hline M. aurum & NCTC $10437^{\mathrm{T}}$ & NCTC \\
\hline M. austroafricanum & DSM $44191^{\mathrm{T}}$ & DSMZ \\
\hline M. diernhoferi & DSM $43524^{\mathrm{T}}$ & DSMZ \\
\hline M. fortuitum & DSM $46621^{\mathrm{T}}$ & DSMZ \\
\hline$M$. gadium & NCTC $10942^{\mathrm{T}}$ & NCTC \\
\hline M. hodleri & DSM $44183^{T}$ & DSMZ \\
\hline M. komossense & ATCC $33013^{\mathrm{T}}$ & $\begin{array}{l}\text { M.-L. Katila, Central Hospital of } \\
\text { Kuopio University }\end{array}$ \\
\hline M. neoaurum & NCTC $10818^{T}$ & NCTC \\
\hline M. obuense & NCTC $10778^{\mathrm{T}}$ & NCTC \\
\hline M. vaccae & NCTC $10916^{\mathrm{T}}$ & NCTC \\
\hline
\end{tabular}

* Equivalent to ATCC $19977^{\mathrm{T}}$ which was used in sequence comparison. 
$\mathrm{G}+\mathrm{C}$ content by HPLC were done as described previously (Minnikin et al., 1980; Luquin et al., 1991; Häggblom et al., 1994; Briglia et al., 1996).

Polyamines. For polyamine analyses the strains were grown on PYE agar plates. Extraction and analysis of polyamines (1,3-diaminopropane, putrescine, cadaverine, symnorspermidine, spermine and tyramine) was done as described previously (Altenburger et al., 1997).

Physiological tests. Physiological tests in microtitre plates were done as described earlier (Kämpfer et al., 1997). Tests were read after $7 \mathrm{~d}$ at $30^{\circ} \mathrm{C}$. Numerical analysis was done using the simple-matching coefficient and the phenogram was generated with the unweighted pair group method with averages (UPGMA) algorithm (Sneath \& Sokal, 1973). For the other physiological determinations methods described in (Levy-Frebault \& Portaels, 1992; Lutz, 1992) were used. The number of strains studied in the numerical taxonomy is the number of OTUs in the phenogram, i.e. 11 strains, the number of characters is 65 (all tests in Table 5). The test error was not estimated.

Ribotyping. For ribotyping cells were collected from an tryptone soy agar plate, suspended in saline in an Eppendorf tube, centrifuged and the pellet vortexed into $1 \mathrm{ml}$ acetone (1 min). After $15 \mathrm{~min}$ at $37^{\circ} \mathrm{C}$ and centrifugation, the supernatant was removed and the cell pellet was dried for $5 \mathrm{~min}$ at $37^{\circ} \mathrm{C}$. The pellet was vortexed into $1 \mathrm{ml}$ chloroform methanol $(2: 1, \mathrm{v} / \mathrm{v})$, incubated for $1 \mathrm{~h}$ at $37^{\circ} \mathrm{C}$, centrifuged, and the washing protocol was repeated once with chloroform/methanol $(2: 1, \mathrm{v} / \mathrm{v})$ and then twice with acetone. The dried pellet was suspended in RiboPrinter sample buffer and frozen and thawed a few times; $30 \mu \mathrm{l}$ of this suspension was analysed using a robotized RiboPrinter Microbial Characterization System (Qualicon) operating as described by Bruce (1996). In every batch of eight samples five molecular mass marker lanes were run also.

Phylogenetic analyses. The ae 2 editor (Maidak et al., 1994) was used to align the 16S rDNA sequence of the isolate MA112/96 ${ }^{\mathrm{T}}$ against the $16 \mathrm{~S}$ rDNA sequences of Mycobacterium species available from the public databases. The method of Jukes \& Cantor (1969) was used to calculate evolutionary distances. Phylogenetic dendrograms were generated using the various treeing algorithms contained in the PHYLIP package (Felsenstein, 1993). The phylogenetic dendrogram was reconstructed from evolutionary distances using the neighbour-joining method (Saitou \& Nei, 1987).

Nucleotide sequence accession numbers. The strain designations and 16S rDNA sequence accession numbers of the Mycobacterium reference strains used in the phylogenetic analyses are as follows: Mycobacterium abscessus ATCC $19977^{\mathrm{T}}$, M29559; Mycobacterium aichiense ATCC $27280^{\mathrm{T}}$, X55598; Mycobacterium aurum ATCC $23366^{\mathrm{T}}$, X55595; Mycobacterium austroafricanum ATCC $33464^{\mathrm{T}}$, X93182; Mycobacterium chitae ATCC $19627^{\mathrm{T}}$, X55603; Mycobacterium chlorophenolicum DSM 43826 ${ }^{\mathrm{T}}$, X79292; Mycobacterium chubuense ATCC 27278, X55596; Mycobacterium diernhoferi ATCC 19340, X55593; Mycobacterium fallax ATCC $35219^{\mathrm{T}}$, M29562; Mycobacterium farcinogenes DSM 43294, X55592; Mycobacterium flavescens ATCC 14474 ${ }^{\mathrm{T}}$, X52932; Mycobacterium fortuitum ATCC $6841^{\mathrm{T}}$, X52933; Mycobacterium gadium ATCC $27726^{\mathrm{T}}$, X55594; Mycobacterium gilvum ATCC $43909^{\mathrm{T}}$, X55599; Mycobacterium hodleri EMI2 ${ }^{\mathrm{T}}$, X93184; Mycobacterium komossense ATCC $33013^{\mathrm{T}}$, X55591; Mycobacterium madagascariense ATCC $49865^{\mathrm{T}}$, X55600; Mycobacterium neoaurum ATCC 25795 terium obuense ATCC $27023^{\mathrm{T}}$, X55597; Mycobacterium parafortuitum DSM 43528, X93183; Mycobacterium senegalense ATCC $35796^{\mathrm{T}}$, M29567; Mycobacterium smegmatis ATCC 14468, X52922; Mycobacterium sphagni ATCC $33026^{\mathrm{T}}$, X55590; Mycobacterium vaccae ATCC $15483^{\mathrm{T}}$, X55601; strain MA112/96 ${ }^{\mathrm{T}}$ DSM $44340^{\mathrm{T}}$, Y08857.

\section{RESULTS}

\section{Morphological characteristics and growth requirements}

The five mycobacterial isolates (MA112/96 ${ }^{\mathrm{T}}$, MA113/96, MA142/96, MA166/96 and MA168/96) grew on TSBA agar as smooth, scotochromogenic colonies of saffron yellow colour. The cells were nonmotile, rod-shaped without branching, non-sporeforming and without capsules. Electron microscopic examination (Fig. 1) showed that the cells were short rods or coccoid (varying between 0.4 and $0.5 \mu \mathrm{m}$ in width, 0.6 and $1.4 \mu \mathrm{m}$ in length) and exhibited a triplelayered structure of the cell wall that is characteristic of mycobacteria with an irregular electron-dense outer layer. Cells were frequently attached to one another.

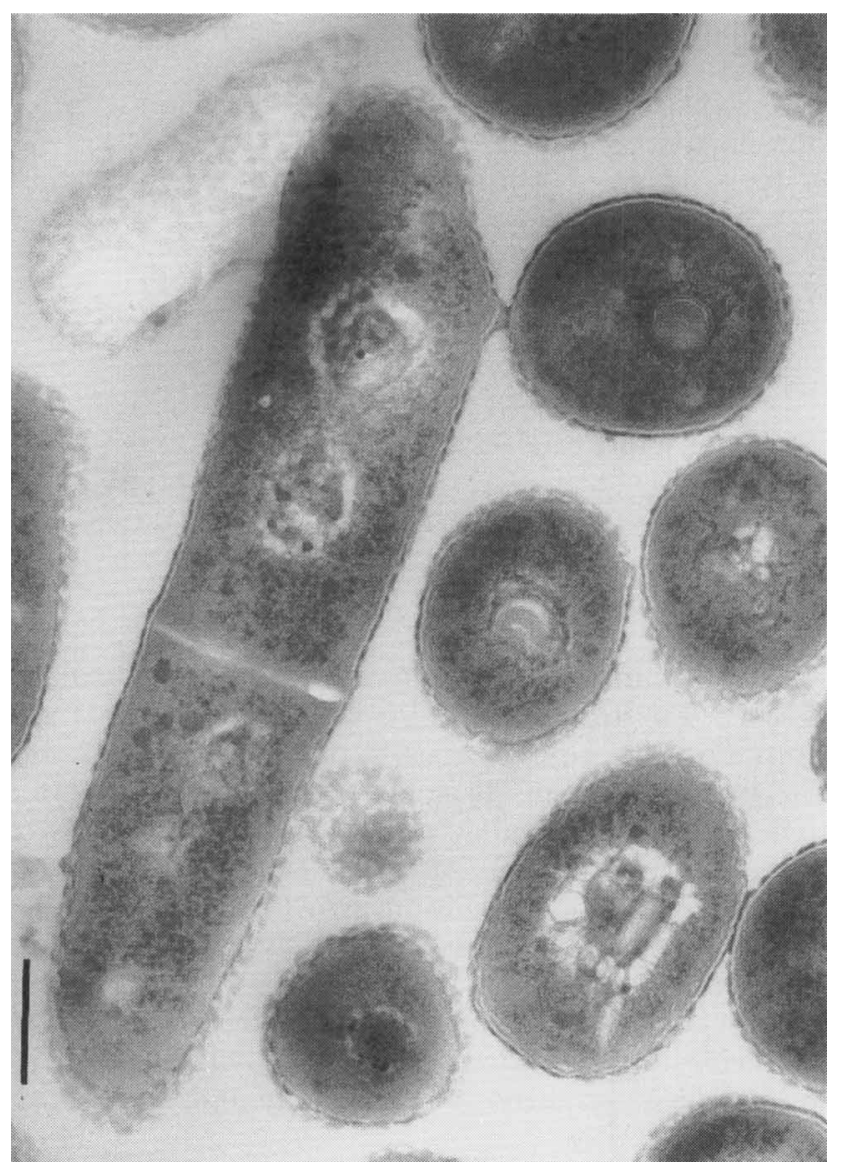

Fig. 1. Thin section of cells of strain MA112/96 ${ }^{\top}$. The perpendicular fashion of cell division of a rod-shaped cell is visible and the triple-layered structure of the cell wall: an irregular electron-dense outer layer, an electron-translucent layer and peptidoglycan layer. Cells were frequently attached to one another by the irregular outer layer. Cells were grown for $7 \mathrm{~d}$ on tryptic soy agar at $28^{\circ} \mathrm{C}$. Bar, $200 \mathrm{~nm}$. 
Table 2. Comparison of selected rapidly growing Mycobacterium species with five new isolates

Strains: 1, New isolates (MA112/96 , MA113/96, MA142/96, MA166/96 and MA168/96);

2, M. abscessus NCTC 10882; 3, M. aurum NCTC $10437^{\mathrm{T}} ; 4$, M. austroafricanum DSM $44191^{\mathrm{T}}$;

$5, M$. diernhoferi DSM 43524 $; 6, M$. gadium NCTC $10942^{\mathrm{T}} ; 7, M$. hodleri DSM $44183^{\mathrm{T}}$;

8, M. komossense ATCC $33013^{\mathrm{T}} ; 9$, M. neoaurum NCTC $10818^{\mathrm{T}} ; 10$, M. vaccae NCTC $10916^{\mathrm{T}}$.

Pigmentation: N, non-chromogenic; P, photochromogenic; S, scotochromogenic.

\begin{tabular}{|c|c|c|c|c|c|c|c|c|c|c|}
\hline \multirow[t]{2}{*}{ Character } & \multicolumn{10}{|c|}{ Strain } \\
\hline & 1 & 2 & 3 & 4 & 5 & 6 & 7 & 8 & 9 & 10 \\
\hline Colonies pigmented & $\mathrm{S}$ & $\mathrm{N}$ & $\mathrm{S}$ & $\mathrm{S}$ & $\mathrm{N}$ & $\mathrm{S}$ & $\mathrm{S}$ & $\mathrm{S}$ & $\mathrm{S}$ & $\mathbf{P}$ \\
\hline \multicolumn{11}{|l|}{ Growth at: } \\
\hline $45^{\circ} \mathrm{C}(5 \mathrm{~d})$ & - & - & - & - & - & - & - & - & - & - \\
\hline $10^{\circ} \mathrm{C}(10 \mathrm{~d})$ & \pm & - & \pm & \pm & - & - & + & + & \pm & \pm \\
\hline $\begin{array}{l}\text { Growth on MacConkey agar without } \\
\text { crystal violet }\end{array}$ & $\begin{array}{l}- \\
-\end{array}$ & + & $\begin{array}{l}- \\
-\end{array}$ & - & - & - & - & - & - & - \\
\hline \multicolumn{11}{|l|}{ Enzymic activities: } \\
\hline$\alpha$-Glucosidase* & + & - & \pm & \pm & - & - & - & \pm & - & + \\
\hline Arylsulfatase & + & + & - & - & - & - & + & - & - & - \\
\hline Catalase at $22{ }^{\circ} \mathrm{C} \dagger$ & + & + & + & + & - & - & + & - & - & + \\
\hline Catalase at $68^{\circ} \mathrm{C} \dagger$ & \pm & - & + & + & + & + & + & \pm & + & + \\
\hline Nitrate reductase & - & - & - & + & + & + & - & - & + & + \\
\hline Tween 80 hydrolysis (10 d) & + & - & + & + & - & + & + & + & + & + \\
\hline Urease & + & + & + & + & + & + & - & + & + & + \\
\hline \multicolumn{11}{|l|}{ Resistance to: $\ddagger$} \\
\hline Isoniazid $\left(1 \mu \mathrm{g} \mathrm{ml}^{-1}\right)$ & - & + & - & - & - & - & + & - & + & - \\
\hline Isoniazid $\left(10 \mu \mathrm{g} \mathrm{ml}^{-1}\right)$ & - & + & - & - & - & - & + & - & - & - \\
\hline Hydroxylamine $\left(500 \mu \mathrm{g} \mathrm{ml}^{-1}\right)$ & - & - & - & - & - & - & - & - & - & - \\
\hline $\mathrm{NaCl}(5 \%)$ & - & + & - & - & - & - & - & - & + & - \\
\hline Picrate $(0.2 \%)$ & + & + & - & + & + & - & + & - & + & - \\
\hline
\end{tabular}

${ }^{*}$ Activity of $\alpha$-glucosidase [mmol h-1 $\left.\left(\mathrm{OD}_{600} \text { unit }\right)^{-1}\right]$;, $\pm 0 \cdot 4 ;+, 0 \cdot 7-1 \cdot 4$.

$\dagger$ Semiquantitative catalase: high catalase foam, $>45 \mathrm{~mm}$; low catalase foam, $<45 \mathrm{~mm}$.

$\ddagger$ Tested in the presence of $0.4 \%$ Tween 80 on Middlebrook $7 \mathrm{H} 10$ plates or medium described by

Levy-Frebault \& Portaels (1992) for the picrate-resistance test.

The optimum growth temperature for the isolates MA112/96 ${ }^{\mathrm{T}}$ and MA166/96 was $30^{\circ} \mathrm{C}$ in TSB medium. On TSBA plates growth occurred within 2-4 d. The five mycobacterial isolates grew at $10^{\circ} \mathrm{C}$ within $10 \mathrm{~d}$. Of all the mycobacterial reference strains tested (listed in Table 1), only $M$. komossense ATCC $33013^{\mathrm{T}}$ grew at $6{ }^{\circ} \mathrm{C}$. The maximum growth temperature for the five new strains was $37^{\circ} \mathrm{C}$. The temperature requirements of the new strains were similar to those of the type strains of $M$. aurum, $M$. austroafricanum, $M$. neoaurum and $M$. vaccae (Table 2). All five isolates stained Gram-positive when young and were acidalcohol-fast.

\section{Identification with PCR}

The PCR amplification of the gene of the secreted $32 \mathrm{kDa}$ protein specific to mycobacteria gave positive results with both tested isolates, MA112/96 ${ }^{\mathbf{T}}$ and MA166/96.

\section{Antimicrobial susceptibility}

The susceptibility of the new isolates to antimicrobial agents used against clinically important mycobacteria are shown in Tables 2 and 3. As compared to the opportunistically pathogenic rapidly growing species $M$. fortuitum, MA112/96 ${ }^{\mathrm{T}}$ and MA166/96 were susceptible to all antimicrobials tested with E-test strips (Table 3), excepting the $\beta$-lactam antibiotics and also chloramphenicol for strain MA112/96 ${ }^{\mathbf{T}}$. The new isolates were also sensitive to rifampin, streptomycin and ethambutol. When tested on plates (with $0.4 \%$ Tween 80 ) the strains were also sensitive to isoniazid and hydroxylamine but resistant to picrate (Table 2).

\section{Cell wall, fatty acids, respiratory quinones and $G+C$ content}

The diagnostic cell wall sugars were arabinose and galactose in isolate MA112/96 ${ }^{\mathrm{T}}$. The cell wall contained meso-diaminopimelic acid as the only diamino 
Table 3. MICs of selected antimicrobial agents for MA112/96 ${ }^{\top}$, MA166/96 and reference strain M. fortuitum DSM $46621^{\top}$, as determined at $35^{\circ} \mathrm{C}$

\begin{tabular}{|c|c|c|c|}
\hline \multirow[t]{2}{*}{ Antimicrobial agent } & \multicolumn{3}{|c|}{ MIC $\left(\mu \mathrm{g} \mathrm{ml}^{-1}\right)$ for: } \\
\hline & MA112/96 ${ }^{\mathrm{T}}$ & MA166/96 & M. fortuitum \\
\hline Amikacin & $0 \cdot 38$ & $0 \cdot 19$ & $1 \cdot 0$ \\
\hline Azithromycin & $0 \cdot 50$ & $0 \cdot 25$ & ND \\
\hline Penicillin G & $>32$ & $>32$ & $>32$ \\
\hline Ceftazidime & $>256$ & $>256$ & $>256$ \\
\hline Chloramphenicol & 12 & 0.75 & $>256$ \\
\hline Ciprofloxacin & $<0.002$ & $<0.002$ & $0 \cdot 023$ \\
\hline Clarithromycin & $0 \cdot 064$ & $<0.016$ & 12 \\
\hline Doxycyclin & $0 \cdot 047$ & $<0.016$ & $0 \cdot 19$ \\
\hline Vancomycin & $0 \cdot 38$ & $0 \cdot 19$ & 32 \\
\hline
\end{tabular}

ND, Not determined.

Table 4. Whole-cell fatty acid compositions of the strain MA112/96 ${ }^{\top}$ and selected type strains of genus Mycobacterium grown on Middlebrook 7H10 agar

Fatty acids: $1, \mathrm{C}_{14: 0} ; 2, \mathrm{C}_{15: 0} ; 3, \mathrm{C}_{16: 1}$ cis $7 ; 4, \mathrm{C}_{16: 1} \operatorname{cis} 9 ; 5, \mathrm{C}_{16: 1}$ cis $10 ; 6, \mathrm{C}_{16: 0} ; 7, \mathrm{C}_{17: 1}$ cis $9 ; 8, \mathrm{C}_{18: 2} ; 9, \mathrm{C}_{18: 1}$ cis 9 ; $10, \mathrm{C}_{18: 1}$ cis $11 ; 11, \mathrm{C}_{18: 0} ; 12,10 \mathrm{Me}-\mathrm{C}_{18: 0} ; 13, \mathrm{C}_{20: 0}$ alcohol; $14, \mathrm{C}_{20: 0}$. The strains are listed in the order of the fatty acid similarity dendrogram as compared to strain MA112/96 . Minor quantities $(<1 \%)$ of the following fatty acids were also found: $\mathrm{C}_{10: 0}$, $\mathrm{C}_{12: 0}, 8 \mathrm{Me}-\mathrm{C}_{16: 0}, 10 \mathrm{Me}-\mathrm{C}_{16: 0}, \mathrm{C}_{17: 1}$ cis 9 and $\mathrm{C}_{17: 0}$ in some of the following strains MA112/96 ${ }^{\mathrm{T}}$, M. abscessus, M. komossense and M. vaccae.

\begin{tabular}{|c|c|c|c|c|c|c|c|c|c|c|c|c|c|c|}
\hline \multirow[t]{2}{*}{ Strain } & \multicolumn{14}{|c|}{ Fatty acid (percentage of total): } \\
\hline & 1 & 2 & 3 & 4 & 5 & 6 & 7 & 8 & 9 & 10 & 11 & 12 & 13 & 14 \\
\hline MA112/96 & $3 \cdot 4$ & $<0.4$ & $2 \cdot 5$ & $2 \cdot 4$ & $7 \cdot 9$ & $19 \cdot 6$ & $13 \cdot 6$ & $0 \cdot 8$ & $21 \cdot 4$ & 0.8 & $1 \cdot 3$ & $16 \cdot 6$ & $9 \cdot 1$ & $<0.4$ \\
\hline M. aurum NCTC $10437^{\mathrm{T}}$ & $3 \cdot 8$ & $<0.4$ & 1.5 & $1 \cdot 1$ & $7 \cdot 6$ & $22 \cdot 4$ & $15 \cdot 4$ & $<0.4$ & $20 \cdot 0$ & $<0.4$ & $1 \cdot 1$ & $13 \cdot 6$ & $13 \cdot 5$ & $<0.4$ \\
\hline M. hodleri DSM $44183^{\mathrm{T}}$ & $5 \cdot 4$ & $1 \cdot 1$ & $2 \cdot 3$ & $2 \cdot 8$ & $8 \cdot 3$ & $19 \cdot 9$ & $18 \cdot 3$ & $0 \cdot 7$ & $23 \cdot 5$ & 0.8 & 0.9 & $13 \cdot 3$ & $2 \cdot 7$ & $<0.4$ \\
\hline M. gadium NCTC $10942^{\mathrm{T}}$ & $3 \cdot 7$ & $<0.4$ & 3.6 & $3 \cdot 6$ & $3 \cdot 7$ & $21 \cdot 9$ & $11 \cdot 2$ & $1 \cdot 1$ & $29 \cdot 4$ & 0.9 & $2 \cdot 7$ & $10 \cdot 6$ & $6 \cdot 8$ & 0.7 \\
\hline M. diernhoferi DSM $43524^{\mathrm{T}}$ & $7 \cdot 7$ & $0 \cdot 5$ & $5 \cdot 4$ & 0.6 & 6.6 & $18 \cdot 2$ & 33.8 & $<0.4$ & $18 \cdot 1$ & $<0.4$ & 0.6 & 4.7 & $3 \cdot 3$ & $0 \cdot 6$ \\
\hline M. vaccae $\mathrm{NCTC} 10916^{\mathrm{T}}$ & $5 \cdot 0$ & $0 \cdot 5$ & $4 \cdot 7$ & 1.7 & $13 \cdot 0$ & $19 \cdot 1$ & $18 \cdot 2$ & 1.9 & $23 \cdot 2$ & $1 \cdot 1$ & $3 \cdot 0$ & 3.5 & $2 \cdot 7$ & 0.5 \\
\hline M. komossense ATCC $33013^{\mathrm{T}}$ & $7 \cdot 8$ & $0 \cdot 2$ & $2 \cdot 1$ & $2 \cdot 6$ & 8.9 & $23 \cdot 7$ & $17 \cdot 4$ & 0.6 & $22 \cdot 2$ & $0 \cdot 4$ & $2 \cdot 1$ & $8 \cdot 4$ & $2 \cdot 4$ & $0 \cdot 3$ \\
\hline M. austroafricanum DSM $44191^{\mathrm{T}}$ & $3 \cdot 2$ & $0 \cdot 3$ & $2 \cdot 7$ & $<0.4$ & $9 \cdot 5$ & $21 \cdot 7$ & $25 \cdot 3$ & 0.4 & $17 \cdot 3$ & $0 \cdot 4$ & 0.9 & $7 \cdot 5$ & $10 \cdot 7$ & $<0.4$ \\
\hline M. neoaurum NCTC $10818^{\mathrm{T}}$ & $4 \cdot 8$ & $<0.4$ & 3.6 & $2 \cdot 6$ & $8 \cdot 6$ & $23 \cdot 6$ & $18 \cdot 4$ & $<0.4$ & 32.4 & $<0.4$ & $1 \cdot 6$ & $2 \cdot 0$ & $1 \cdot 2$ & $1 \cdot 3$ \\
\hline M. abscessus NCTC 10882 & $6 \cdot 0$ & $0 \cdot 3$ & 1.8 & $4 \cdot 7$ & $10 \cdot 4$ & $34 \cdot 1$ & $<0.4$ & 0.6 & 35.5 & 0.6 & $1 \cdot 0$ & 3.9 & $<0.4$ & $<0.4$ \\
\hline
\end{tabular}

acid. The whole-cell fatty acid patterns of strain MA112/96 ${ }^{\mathrm{T}}$ and selected reference strains are shown in Table 4. The main fatty acids of MA112/96 ${ }^{\mathrm{T}}$ were $\mathrm{C}_{18: 1}$ cis $9(21 \%), \mathrm{C}_{16: 0}(20 \%)$, tuberculostearic acid $10 \mathrm{Me}-\mathrm{C}_{18: 0}(17 \%), \mathrm{C}_{17: 1}$ cis $9(14 \%)$ and $\mathrm{C}_{16: 1}$ cis 10 $(8 \%)$. Also an alcohol of 20 carbon atom chain-length was a major component $(9 \%)$. The quantity of tuberculostearic acid in strain MA112/96 $6^{\mathrm{T}}$ was high $(17 \%)$ when grown at $28^{\circ} \mathrm{C}$ and even higher $(22 \%)$ when grown at $37^{\circ} \mathrm{C}$. The five new mycobacterial isolates had similar fatty acid profiles (data not shown), distinct from those of the other rapidly growing mycobacterial species (Table 4). The fatty acid composition of the new isolates was different from both $M$. abscessus and from $M$. komossense (Table 4). Of the tested species (Fig. 2), M. aurum and M. hodleri had fatty acid profiles most similar to those of the new isolates, excepting for the lower amounts of tuberculostearic acid and $\mathrm{C}_{20}$ alcohol which was low in $M$. hodleri. Of the total amount of menaquinones, strain MA $112 / 96^{\mathrm{T}}$ had $90 \%$ of MK- $9\left(\mathrm{H}_{2}\right)$ and $10 \%$ of MK$8\left(\mathrm{H}_{2}\right)$. The $\mathrm{G}+\mathrm{C}$ content of strain MA168/96 was $72 \cdot 9 \mathrm{~mol} \%$.

\section{Polar lipids}

Two-dimensional TLC analysis showed that the isolates MA112/96 ${ }^{\mathrm{T}}$, MA142/96 and MA166/96 had identical polar lipid patterns. Fig. 3 shows the polar lipids of MA112/96 ${ }^{\mathrm{T}}$ and those of $M$. komossense 


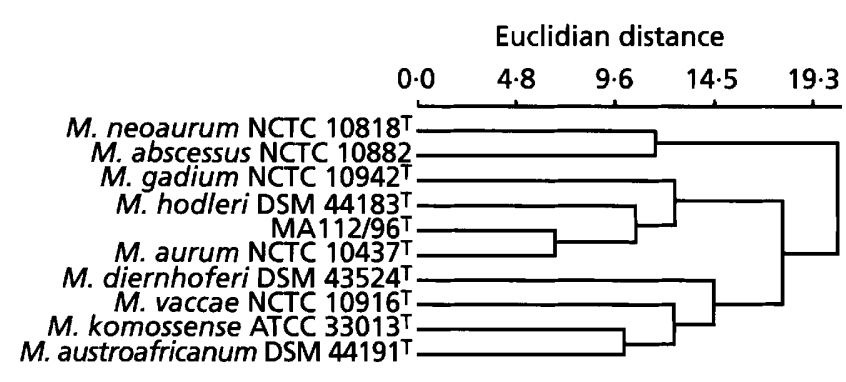

Fig. 2. Euclidian distance dendrogram based on the whole-cell fatty acid compositions of the new mycobacterial isolate MA $112 / 96^{\top}$ and the type strains of the nine most closely related mycobacterial species.
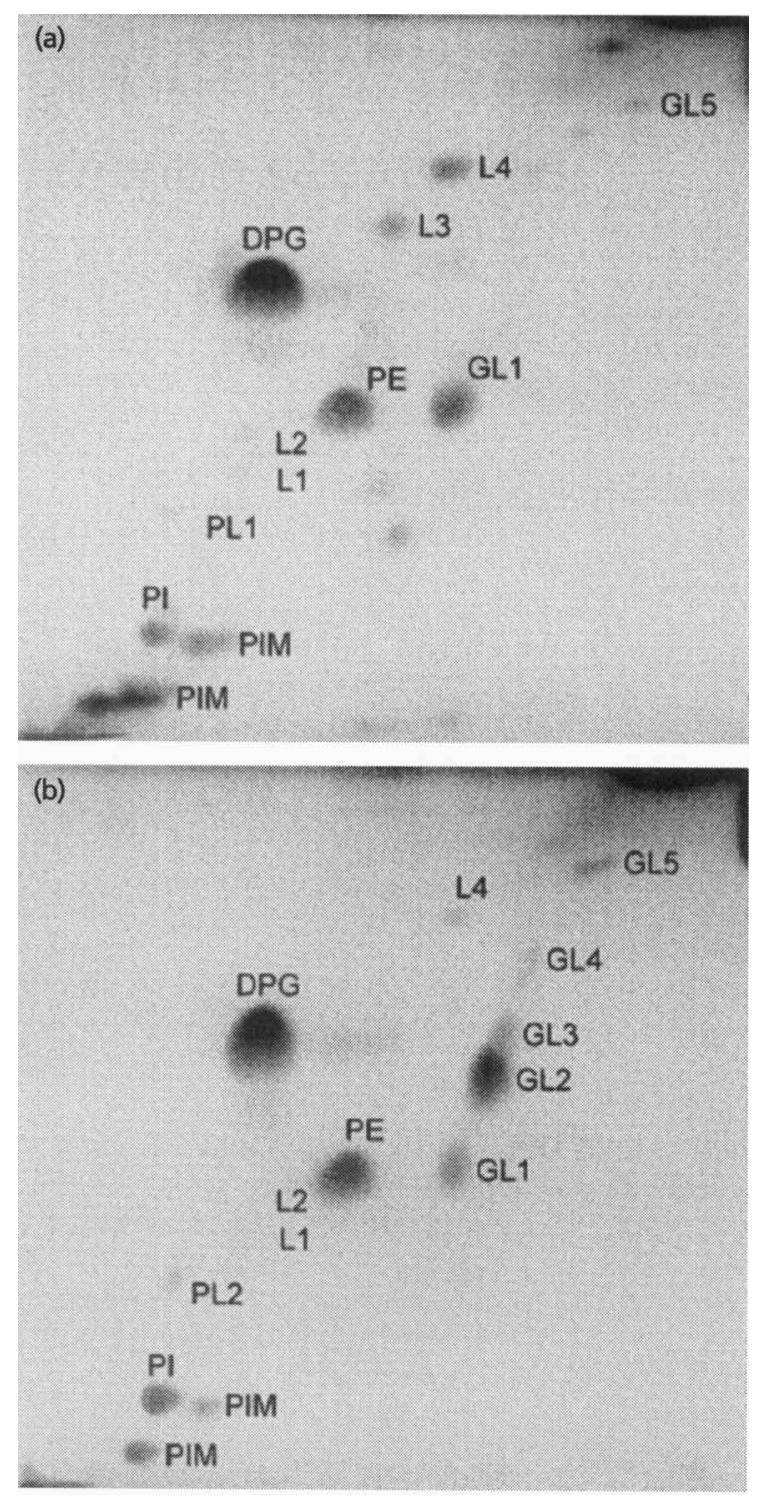

Fig. 3. Two-dimensional thin-layer chromatographs of total lipids of (a) MA112/96 ${ }^{\top}$ and (b) M. komossense ATCC $33013^{\top}$. Abbreviations: DPG, diphosphatidylglycerol; GL, glycolipid; $L$, lipid; $\mathrm{PE}$, phosphatidylethanolamine; $\mathrm{PI}$, phosphatidylinositol PIM, phosphatidylinositolmannoside; PL, unknown polar lipid.

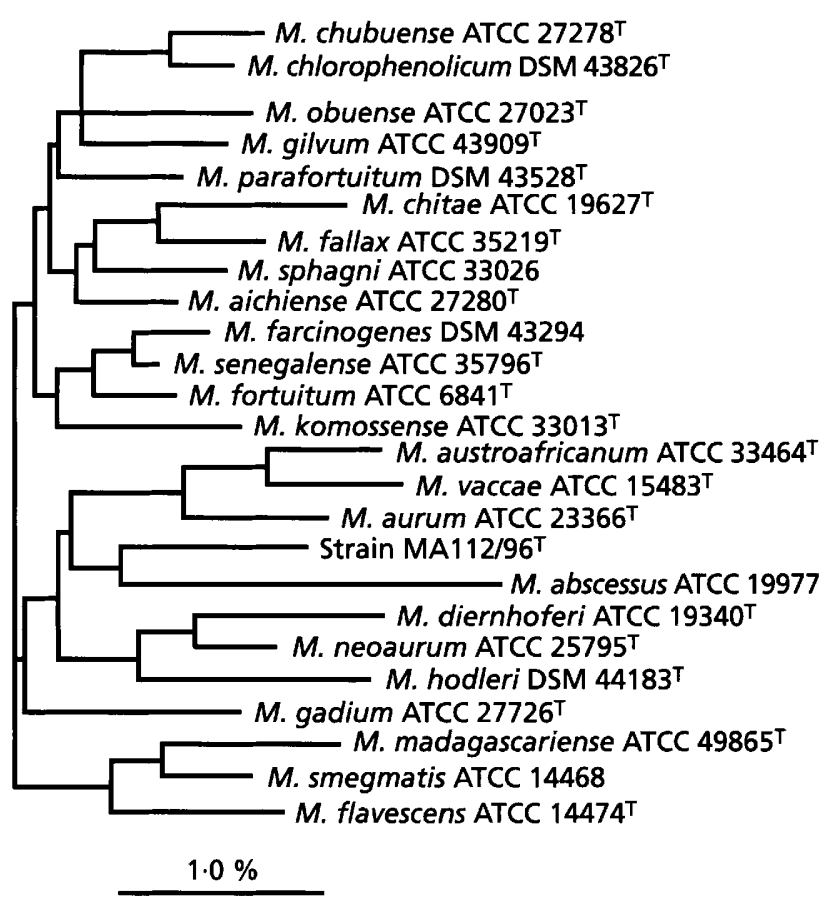

Fig. 4. 16S rDNA sequence based phylogenetic dendrogram reconstructed from evolutionary distances using the neighbourjoining method (Jukes \& Cantor, 1969). Scale bar, 1 inferred nucleotide substitution per 100 nucleotides.

ATCC $33013^{\mathrm{T}}$. Both displayed PE, PI, PIM and DPG as the major phospholipids. The presence of one unknown lipid (L3) in MA112/96 ${ }^{\mathrm{T}}$ (Fig. 3a) and three glycolipids (GL2, GL3 and GL4) in $M$. komossense (Fig. 3b) distinguished the two species.

\section{Mycolic acids}

The isolate MA112/96 ${ }^{\mathrm{T}}$ contained $\alpha$-mycolic acids, keto-mycolates and wax esters ( $\omega$ carboxy mycolates and eicosanol). The overall number of carbon atoms in mycolic acids was 60-90. The chain length of mycolic acids was Mycobacterium specific and the composition differentiated tested strains from $M$. komossense, which had also methoxy mycolic acids (Minnikin et $a l ., 1985)$. The same distribution of mycolic acids has been found in $M$. aurum, $M$. austroafricanum, $M$. diernhoferi, $M$. gadium, $M$. hodleri and $M$. neoaurum (Minnikin et al., 1985; Kleespies et al., 1996).

\section{Polyamines}

The analysis of the polyamine patterns of the reference species $M$. komossense, $M$. aichiense and $M$. fortuitum as well as the new isolates demonstrated that in mycobacteria the overall polyamine content is rather low $\left[\leqslant 0.05 \mu \mathrm{mol}(\mathrm{g} \text { dry } \mathrm{wt})^{-1}\right]$. Putrescine and spermidine were found in all strains and usually spermidine was a predominant compound in the polyamine patterns. 
Table 5. Ability of the five new mycobacterial isolates and six type strains of closely related Mycobacterium species to degrade various substrates

Strains: 1, New isolates (MA112/96 ${ }^{\mathrm{T}}$, MA113/96, MA142/96, MA166/96 and MA168/96); 2, M. komossense ATCC 33013 ${ }^{\mathrm{T}}$;

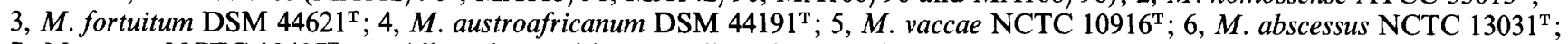
7, M. aurum NCTC $10437^{\mathrm{T}}$. +, All strains positive; -, all strains negative; numbers are percentages of positive isolates. pNP, para-nitrophenyl; pNA, para-nitroanilide. Acidification of sugars was in some cases weak and difficult to interpret. For this reason no detailed results are given here. All strains were able to utilize gluconate, D-glucose, propionate and fumarate as sole source of carbon and all strains hydrolysed L-alanine-pNA. None of the strains was able to utilize D-melibiose, citrate (in some cases a weak response was visible after $10 \mathrm{~d}$ incubation), mesaconate, L-aspartate, L-histidine, L-tryptophan, 3-hydroxybenzoate as sole source of carbon and none hydrolysed pNP- $\beta$-D-galactopyranoside, pNP- $\beta$-D-glucuronide, 2-deoxythymidine- $5^{\prime}$-pNP-phosphate and L-glutamate- $\gamma$-3-carboxy-pNA.

\begin{tabular}{|c|c|c|c|c|c|c|c|}
\hline \multirow[t]{2}{*}{ Metabolic property } & \multicolumn{7}{|c|}{ Strain } \\
\hline & 1 & 2 & 3 & 4 & 5 & 6 & 7 \\
\hline \multicolumn{8}{|l|}{ Assimilation of: } \\
\hline L-Arabinose & $\begin{array}{l}+0 \\
+\end{array}$ & $\stackrel{+}{-}$ & - & + & $\overline{+}$ & \pm & + \\
\hline$p$-Arbutin & 20 & - & - & - & - & - & - \\
\hline D-Cellobiose & - & - & + & - & - & - & - \\
\hline D-Fructose & 40 & - & - & + & + & - & + \\
\hline D-Galactose & - & - & - & - & + & - & - \\
\hline D-Mannose & + & - & - & + & + & + & + \\
\hline D-Maltose & + & - & - & - & - & - & - \\
\hline L-Rhamnose & + & - & + & - & + & - & - \\
\hline D-Ribose & + & - & - & - & - & - & - \\
\hline D-Sucrose & - & - & - & + & + & - & + \\
\hline Salicin & - & - & - & - & - & + & - \\
\hline D-Trehalose & + & - & + & + & + & + & + \\
\hline D-Xylose & + & - & + & + & + & - & + \\
\hline Adonitol & + & - & - & - & + & - & + \\
\hline i-Inositol & + & - & + & + & + & - & + \\
\hline Maltitol & + & - & - & - & - & - & - \\
\hline D-Mannitol & + & - & + & + & + & - & + \\
\hline D-Sorbitol & + & - & + & - & + & - & - \\
\hline Putrescine & + & + & + & + & - & + & + \\
\hline Acetate & 40 & + & + & + & + & + & + \\
\hline cis-Aconitate & + & - & - & + & - & - & - \\
\hline Adipate & 20 & - & - & - & + & - & - \\
\hline 4-Aminobutyrate & 20 & + & + & - & - & + & + \\
\hline Azelate & - & - & - & + & - & - & + \\
\hline Glutarate & + & - & - & + & + & - & + \\
\hline DL-3-Hydroxybutyrate & + & + & - & + & + & + & + \\
\hline Itaconate & + & - & - & - & - & - & - \\
\hline DL-Lactate & + & - & - & + & + & - & + \\
\hline L-Malate & 80 & + & + & - & + & - & - \\
\hline Oxoglutarate & 80 & - & - & - & - & - & - \\
\hline Pyruvate & + & + & + & + & + & - & + \\
\hline Suberate & - & - & - & + & + & - & - \\
\hline L-Alanine & + & - & - & - & + & - & - \\
\hline$\beta$-Alanine & 60 & - & - & - & - & + & - \\
\hline L-Leucine & + & + & + & - & - & + & + \\
\hline L-Ornithine & 80 & - & + & + & + & + & - \\
\hline L-Phenylalanine & 20 & - & - & - & - & - & - \\
\hline L-Proline & + & - & - & - & + & + & - \\
\hline L-Serine & - & - & - & - & - & + & - \\
\hline 4-Hydroxybenzoate & - & - & - & + & - & - & - \\
\hline Phenylacetate & - & - & + & - & - & + & - \\
\hline \multicolumn{8}{|l|}{ Hydrolysis of: } \\
\hline Aesculin & - & - & - & - & - & + & - \\
\hline pNP- $\alpha$-D-glucopyranoside & 20 & - & - & + & + & + & + \\
\hline pNP- $\beta$-D-glucopyranoside & 80 & + & + & - & + & + & - \\
\hline bis-pNP-phosphate & + & - & - & + & + & - & + \\
\hline pNP-phenyl-phosphonate & 80 & - & - & - & + & - & + \\
\hline $\begin{array}{l}\text { pNP-phosphoryl-choline } \\
\text { L-Proline-pNA }\end{array}$ & $\begin{array}{c}40 \\
+\end{array}$ & $\bar{t}$ & $\begin{array}{l}+ \\
+\end{array}$ & $\begin{array}{l}- \\
-\end{array}$ & $\begin{array}{l}+ \\
+\end{array}$ & - & $\begin{array}{l}+ \\
-\end{array}$ \\
\hline
\end{tabular}




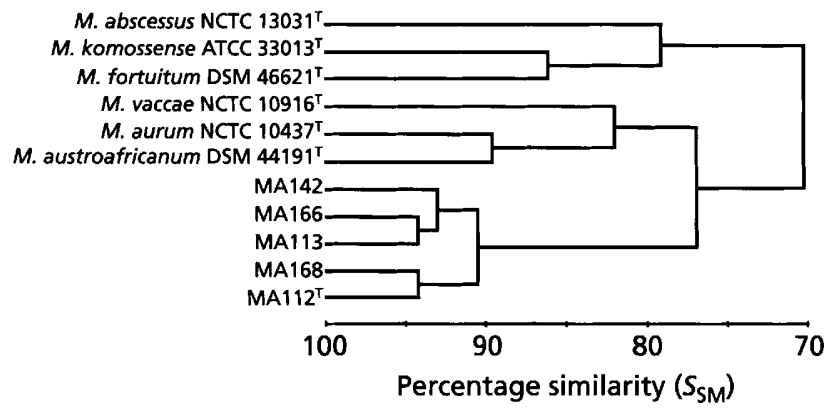

Fig. 5. Phenogram showing the relationships of the five new mycobacterial isolates as compared to the type strains of mycobacterial species most closely related by $16 \mathrm{~S}$ rDNA.

\section{$16 \mathrm{~S}$ rDNA sequence analysis}

The almost complete $16 \mathrm{~S}$ rDNA sequence of the isolate MA112/96 ${ }^{\mathrm{T}}$ (Y08857) comprising 1478 nucleotides [ $>95 \%$ of the Escherichia coli sequence (Brosius et al., 1978)] was used in this study. The phylogenetic dendrogram shown in Fig. 4 was reconstructed from evolutionary distances (Jukes \& Cantor, 1969) by the neighbour-joining method (Saitou \& Nei, 1987). A total of 1243 nucleotides present in all strains between positions 39 and 1376 (E. coli positions; Brosius et al., 1978) were used for this analysis. The phylogenetic dendrogram (Fig. 4) shows isolate MA112/96 $6^{\mathrm{T}}$ to fall within the radiation of the genus Mycobacterium. Sequence of the 16S rDNA in the Mycobacterium specific hypervariable region (E. coli positions 129260) of isolate MA166/96 was identical to that of MA112/96 ${ }^{\mathrm{T}}$. Isolate MA112/96 ${ }^{\mathrm{T}}$ showed $16 \mathrm{~S}$ rDNA sequence similarity in the range $95 \cdot 8-98 \cdot 1 \%(M$. komossense) to the species of the genus Mycobacterium shown in Fig. 4. Even though the overall highest sequence similarity of MA112/96 ${ }^{\mathrm{T}}$ was with $M$. komossense ATCC $33013^{\mathrm{T}}$; the closest species in the 16S rDNA dendrogram was $M$. abscessus ATCC $19977^{\mathrm{T}}$ due to the treeing algorithm and how it calculates the alignment. In the 16S rDNA dendrogram the next closest species were $M$. aurum, $M$. vaccae and $M$. austroafricanum.

\section{Physiological properties}

The substrate utilization of the new isolates were compared to that of the type strains of the phylogenetically closest six species in Table 5. The new isolates used a broader spectrum of carbon sources for growth than the reference species. The ability to assimilate D-maltose, D-ribose, maltitol and itaconate differentiated the new isolates from type strains of $M$. komossense, $M$. fortuitum, $M$. austroafricanum, $M$. vaccae, $M$. abscessus and $M$. aurum. The physiological tests showed (Table 5, Fig. 5) that the new isolates form a homogeneous group distinct from the mycobacterial type strains listed above.

Scotochromogenic pigment formation separates the new isolates from $M$. abscessus, $M$. diernhoferi and $M$. vaccae (Table 2). The new isolates did not grow on MacConkey agar without crystal violet like $M$. abscessus did. Classical mycobacterial tests (Table 2) showed the new isolates to be most similar to $M$. aurum and $M$. austroafricanum, the next closest species were $M$. komossense and $M$. vaccae while $M$. abscessus differed in most tests.

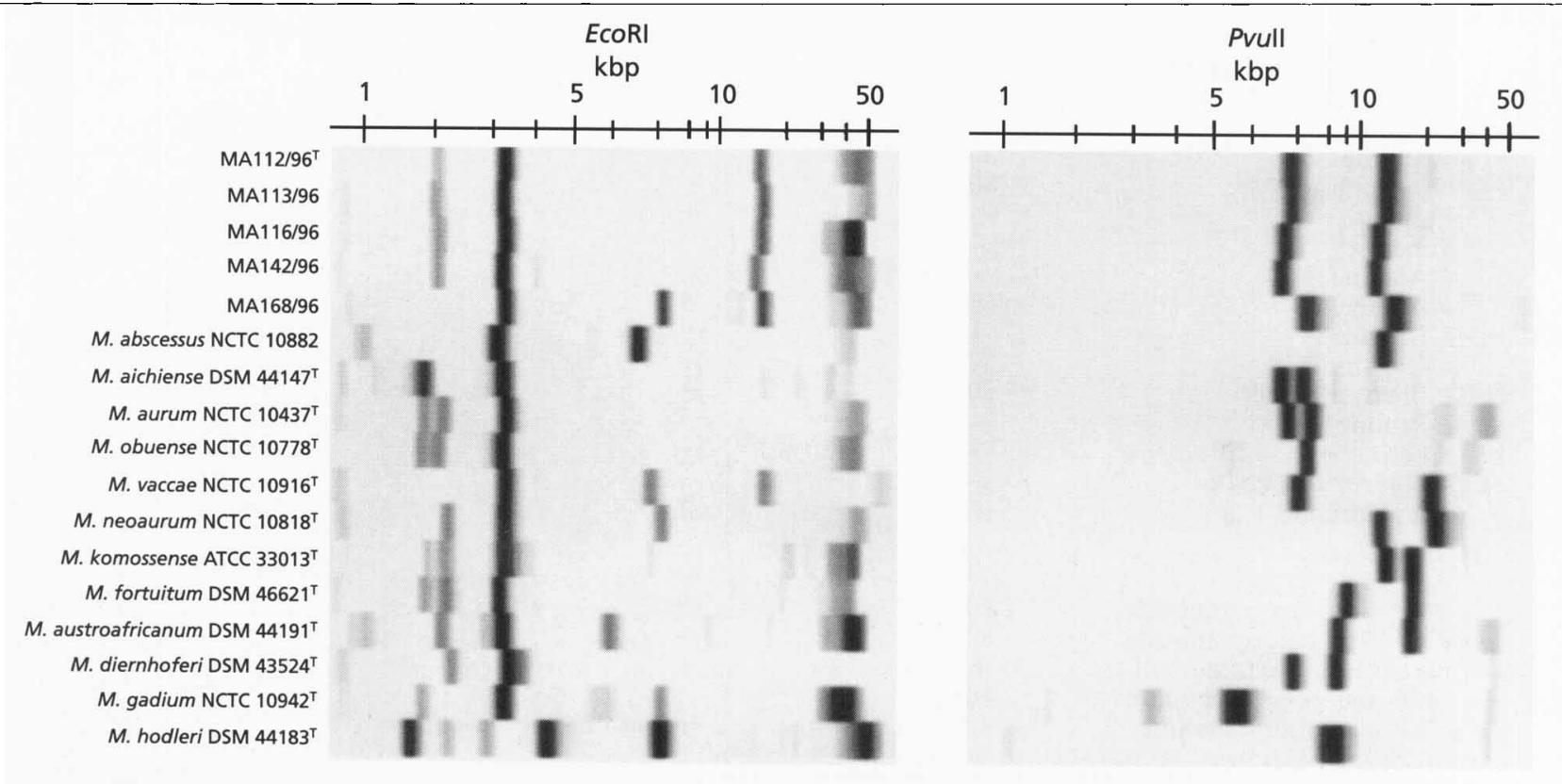

Fig. 6. Ribotypes obtained after digestion with EcoRI or Pvull and hybridization of the $E$. coli $r$ rnB operon of strains MA112/96 ${ }^{\top}$, MA113/96, MA142/96, MA166/96, MA168/96 and of type strains of selected Mycobacterium species. 


\section{Ribotyping}

The five new isolates and 12 most closely related mycobacterial species were ribotyped with two restriction enzymes and the results are shown in Fig. 6. EcoRI yielded ribotyping patterns with 4-7 bands in the size range $1-50 \mathrm{~kb}$. PvuII yielded $2-5$ bands of $3-40 \mathrm{~kb}$ from the different mycobacterial species. The new isolates showed four bands $(2,3,15$ and $40-50 \mathrm{~kb})$ with $E c o$ RI and two bands ( 7 and $12 \mathrm{~kb}$ ) with $P v u I I$. These patterns allow for a species recognition of the new isolates from the 12 closest species of mycobacteria (cf. Fig. 6 to Fig. 4). The $12-15 \mathrm{~kb}$ band but not the $7 \mathrm{~kb} P v u \mathrm{II}$ band, typical of the new isolates, was also present in $M$. abscessus. $7 \mathrm{~kb}$ band, but not the PvuII $12-15 \mathrm{~kb}$ band, was present in $M$. aurum and $M$. vaccae, which were in the same $16 \mathrm{~S}$ rDNA cluster with the new isolates (Fig. 4). M. hodleri differed in ribotype from all the other species. Based on these results, the new strains are concluded to represent a new species of Mycobacterium, to which the name $M$. murale is proposed.

\section{DISCUSSION}

In this paper we describe a new mycobacterial species, $M$. murale, with strain MA1 $12 / 96^{\mathrm{T}}$ proposed as the type strain. Phylogenetical and chemotaxonomic characterization, together with PCR amplification of a DNA fragment specific for a mycobacterial antigen (Soini et al., 1992) showed that the five isolates, representing actinomycetes that colonize waterdamaged building materials were mycobacteria. The characteristics of the new isolates which formed a homogeneous group fit the description of mesophilic, aerobic, rapidly growing, pigmented mycobacteria which stain weakly Gram-positive and are genus specifically acid-alcohol-fast. Mycobacteria were not found in non-water damaged parts of the same building materials (Andersson et al., 1997).

The 16S rDNA sequence of strain MA112/96 ${ }^{\mathrm{T}}$ contains all the signature nucleotides defined for the family Mycobacteriaceae (Stackebrandt et al., 1997). 16S rDNA sequence comparisons demonstrated the distinct lineage of strain MA1 $12 / 96^{\mathrm{T}}$ within the radiation of the genus Mycobacterium. This was confirmed by phylogenetic dendrogram and also in the range of $16 \mathrm{~S}$ rDNA sequence similarity values to the closest relatives within this genus. The physiological and chemotaxonomic properties of strain MA112/96 were compared to the nine most closely related mycobacterial species selected by $16 \mathrm{~S}$ rDNA sequence data, up to $98 \cdot 1 \%$ similarity to MA1 $12 / 96^{\mathrm{T}}$. The $16 \mathrm{~S}$ rDNA sequence data along with the morphological, physiological and chemotaxonomic data presented confirm the novel species status of this strain.

The results of the carbon substrate utilization tests were confirmed by the system used by (Tsukamura et al., 1983; Tsukamura \& Ichiyama, 1986) with some of the tested strains shared in both systems. $M$. murale could use a much broader set of compounds as carbon sources for growth than M. komossense ATCC $33013^{\mathrm{T}}$ or M. abscessus NCTC $13031^{\mathrm{T}}$.

MA112/96 ${ }^{\mathrm{T}}$ could be easily identified as a member of the genus Mycobacterium and differentiated from all other genera of the suborder Corynebacterineae by the occurrence of a multi spot mycolic acid pattern detected on TLC. MA112/96 $6^{\mathrm{T}}$ synthesized $\alpha$ mycolates, keto-mycolates and the wax esters. This pattern is also present in the closely related species $M$. aurum, M. vaccae and $M$. austroafricanum, but here $\alpha^{\prime}$ mycolates are found in addition to the other three mycolates. Another member of this taxon, $M$. abscessus, is easily differentiated from the others by its simple mycolate pattern containing $\alpha$-mycolates and $\alpha^{\prime}$-mycolates.

Previously, it has been shown that the polyamine content of the mycolic-acid-containing genera Corynebacterium and Tsukamurella is rather low and suitable for distinguishing members of these two genera from other coryneform genera (Altenburger et al., 1997). The finding of extremely low polyamine concentrations in mycobacteria indicates that this feature is a characteristic of mycolic acid containing bacteria and might be useful for distinction from other groups. However, the polyamine content of the mycobacterial reference strains were found to be significantly lower than in Corynebacterium, Tsukamurella (Altenburger et al., 1997) and Gordonia species (H.-J. Busse, unpublished data). The polyamine contents of the new mycobacterial isolates were in the same range as the reference strains of the genus Mycobacterium, indicating that these isolates were mycobacteria.

Some rapidly growing mycobacteria may cause infections that are difficult to treat due to the widespread antimicrobial resistance, including the specific antituberculosis drugs. The new Mycobacterium species described in this paper represents an antimicrobial susceptibility profile commonly encountered among apathogenic environmental mycobacteria. However, the presence of mycobacteria at high density $\left(10^{6}\right.$ c.f.u. $\left.\mathrm{g}^{-1}\right)$ in indoor building material may expose the occupants to mycobacterial antigens.

Because the number of environmental mycobacteria that may be opportunistic pathogens in certain circumstances is growing, there is a need for simple identification methods. Our results show that ribotyping together with whole-cell fatty acid analysis provides an option for two-step differentiation of closely related mycobacterial species. The whole-cell fatty acid composition of MA112/96 $6^{\mathrm{T}}$ is typical of mycobacteria, but contains larger amounts of tuberculostearic acid (17-22\%) than its closest relatives. MA112/96 $6^{\mathrm{T}}$ contained large quantities of $\mathrm{C}_{17: 1}$ cis 9 and $\mathrm{C}_{20: 0}$ alcohol unlike $M$. abscessus and also $\mathrm{C}_{16: 0}$ and $\mathrm{C}_{18: 1}$ cis 9 . This report on the use of ribotyping to distinguish related mycobacterial species, is to our knowledge the first one of its kind. Amplified rDNA restriction analysis (ARDRA) has 
been used to differentiate several mycobacterial species by using two or three different restriction enzymes (Vaneechoutte et al., 1993). Although the total number of strains ribotyped is yet low, the results indicate that $E c o$ RI and PvuII can be used to differentiate the tested 13 species. The slightly different ribotype patterns for MA142/96 and MA166/96 with PvuII and that of MA168/96 with EcoRI could be explained by a difference in restriction sites. $M$. hodleri DSM $44183^{\mathrm{T}}$ displayed an EcoRI multiband ribotype with no similarity to any of the other mycobacterial species. Due to the unusual ribotype, the analysis of $M$. hodleri was repeated with a new culture retrieved from the DSMZ (German Collection of Microorganisms and Cell Cultures) with identical results. Although species with multiple different rRNA operons have been described (Mylvaganam \& Dennis, 1992; Ninet et al., 1996; Rainey et al., 1996), in the sequencing of $M$. hodleri there was no evidence of operons with different sequence (Kleespies et al., 1996). Fast-growing mycobacteria have two ribosomal operons while slowgrowing species usually have one (Domenech et al., 1994; Ji et al., 1994). The single-band ribotype by $P v u I I$ for M. obuense (Fig. 5) indicates that this species may possess only one $r r n$ operon as is the case for $M$. abscessus (Ninet et al., 1996).

\section{Description of Mycobacterium murale sp. nov.}

Mycobacterium murale [mu.ra'le. L. adj. muralis, -le pertaining or belonging to wall(s)].

Gram-positive, aerobic, acid-alcohol-fast, non-spore forming, non-motile rods or coccoid cells without branching (0.4-0.5 $\mu \mathrm{m}$ in width, $0.6-1.4 \mu \mathrm{m}$ in length). Smooth, scotochromogenic colonies of saffron yellow colour on TSBA agar. Cells have a triple-layered structure that is typical of mycobacteria visible by electron microscope. The temperature range for growth is $10-37^{\circ} \mathrm{C}$, optimum at $30^{\circ} \mathrm{C}$. The cell wall contains arabinose, galactose and meso-diaminopimelic acid. Contains $\alpha$-mycolic acids, keto-mycolates and wax esters ( $\omega$ carboxy mycolates and eicosanol). Mainly straight-chain saturated $\left(\mathrm{C}_{16: 0}\right)$ and monounsaturated $\left(\mathrm{C}_{16: 1}\right.$ cis $10, \mathrm{C}_{17: 1}$ cis $9, \mathrm{C}_{18: 1}$ cis 9$)$ fatty acids, $\mathrm{C}_{20: 0}$ alcohol and tuberculostearic acid $(17 \%$ at $28^{\circ} \mathrm{C}$ ). The $\mathrm{G}+\mathrm{C}$ content is $72.9 \mathrm{~mol} \%$. The main menaquinone is MK- $9\left(\mathrm{H}_{2}\right)$. Contains phosphatidylethanolamine, diphosphatidylglycerol, phosphatidylinositol, phosphatidylinositolmannosides. Polyamine content is low. Yields two major bands, 7 and $12-15 \mathrm{~kb}$, upon cleavage with $P v u \mathrm{II}$ and hybridization to the full ribosomal operon probe of $E$. coli. $\alpha-$ Glucosidase, arylsulfatase, catalase- and urease-positive. Hydrolyses Tween 80 ; nitrate-reductase-negative. Does not tolerate $5 \% \mathrm{NaCl}$ or grow on MacConkey agar without crystal violet. Assimilates D-maltose, Dribose, adonitol, i-inositol, maltitol, D-mannitol, Dsorbitol and itaconate but not D-sucrose, salicin, aesculin, D-melibiose, citrate, mesaconate, L-aspartate, L-histidine, L-tryptophan or 3-hydroxybenzoate. No hydrolysis of $\mathrm{pNP}-\beta$-D-galactopyranoside, $\mathrm{pNP}-\beta$-Dglucuronide, 2-deoxythymidine- $5^{\prime}$-pNP-phosphate and L-glutamate- $\gamma$-3-carboxy-pNA. Sensitive to amikacin, azithromycin, ciprofloxacin, chlarithromycin, doxycyclin, vancomycin, rifampin, streptomycin and ethambutol but resistant to isoniazid, penicillin $\mathrm{G}$, ceftazidime and chloramphenicol. Isolated from water-damaged indoor building material, Finland. MA112/96 ${ }^{\mathrm{T}}$ is the type strain of the species and has been deposited in the DSMZ as DSM $44340^{\mathrm{T}}$.

\section{ACKNOWLEDGEMENTS}

We thank Professor Dr Hans G. Trüper for help with the Latin construction of the new species name. We thank Riitta Boeck, Tuija Pirttijärvi, Irina Tsitko, Kaisa Siikanen and Leena Steininger for assistance. This work was financially supported by The Foundation for Work and Environment (M.S.-S., M.A.A.) and The Academy of Finland (R.V., H.J.B., M.S.-S.).

\section{REFERENCES}

Altenburger, P., Kämpfer, P., Akimov, V. N., Lubitz, W. \& Busse, H.-J. (1997). Polyamine distribution in Actinomycetes with group B peptidoglycan and species of the genera Brevibacterium, Corynebacterium, and Tsukamurella. Int J Syst Bacteriol 47, $270-277$.

Andersson, M., Laukkanen, M., Nurmiaho-Lassila, E.-L., Rainey, F., Niemela, S. \& Salkinoja-Salonen, M. (1995). Bacillus thermosphaericus sp. nov. a new thermophilic ureolytic Bacillus isolated from air. Syst Appl Microbiol 18, 203-220.

Andersson, M. A., Nikulin, M., Köljalg, U., Andersson, M. C., Rainey, F., Reijula, K., Hintikka, E.-L. \& Salkinoja-Salonen, M. (1997). Bacteria, molds, and toxins in water-damaged building materials. Appl Environ Microbiol 63, 387-393.

Briglia, M., Rainey, F. A., Stackebrandt, E., Schraa, G. \& SalkinojaSalonen, M. S. (1996). Rhodococcus percolatus sp. nov., a bacterium degrading 2,4,6-trichlorophenol. Int J Syst Bacteriol 46, 23-30.

Brosius, J., Palmer, M. L., Kennedy, P. J. \& Noller, H. F. (1978). Complete nucleotide sequence of the 16S ribosomal RNA gene from Escherichia coli. Proc Natl Acad Sci USA 75, 4801-4805.

Bruce, J. (1996). Automated system rapidly identifies and characterizes microorganisms in food. Food Technol 50, 77-81.

Domenech, P., Menendez, M. C. \& Garcia, M. J. (1994). Restriction fragment length polymorphisms of $16 \mathrm{~S}$ rRNA genes in the differentiation of fast-growing mycobacterial species. FEMS Microbiol Lett 116, 19-24.

Felsenstein, J. (1993). PHYLIP (phylogenetic inference package) version 3.5.1. Department of Genetics, University of Washington, Seattle, USA.

Flannigan, B. (1995). Nature, sources and toxicity of pollutants of indoor air. In Indoor Air Quality : a Comprehensive Reference Book, pp. 139-159. Edited by M. Maroni, B. Seifert \& T. Lindvall. Amsterdam: Elsevier.

Guay, D. R. P. (1996). Nontuberculous mycobacterial infections. Ann Pharmacother 30, 819-830.

Hăggblom, M. M., Nohynek, L. J., Palleroni, N. J., Kronqvist, K., Nurmiaho-Lassila, E.-L., Salkinoja-Salonen, M., Klatte, S. \& Kroppenstedt, R. M. (1994). Transfer of polychlorophenol- 
degrading Rhodococcus chlorophenolicus (Apajalahti et al. 1986) to the genus Mycobacterium as Mycobacterium chlorophenolicum comb. nov. Int J Syst Bacteriol 44, 485-493.

Hirai, Y. (1991). Survival of bacteria under dry conditions: from a viewpoint of nosocomial infection. $J$ Hosp Infect 19, 191-200. Ji, Y.-E., Colston, M. J. \& Cox, R. A. (1994). The ribosomal RNA $(r r n)$ operons of fast-growing mycobacteria: primary and secondary structures and their relation to $r r n$ operons of pathogenic slow-growers. Microbiology 140, 2829-2840.

Jukes, T. H. \& Cantor, C. R. (1969). Evolution of protein molecules. In Mammalian Protein Metabolism, pp. 21-132. Edited by H. N. Munro. New York: Academic Press.

Kămpfer, P., Denner, E. B. M., Meyer, S., Moore, E. R. B. \& Busse, H.-J. (1997). Classification of "Pseudomonas azotocolligans" Anderson 1955, 132, in the genus Sphingomonas as Sphingomonas trueperi sp. nov. Int J Syst Bacteriol 47, 577-583.

Kleespies, M., Kroppenstedt, R. M., Rainey, F. A., Weber, L. E. \& Stackebrandt, E. (1996). Mycobacterium hodleri sp. nov., a new member of the fast-growing mycobacteria capable of degrading polycyclic aromatic hydrocarbons. Int $J$ Syst Bacteriol 46, 683-687.

Levy-Frebault, V. V. \& Portaels, F. (1992). Proposed minimal standards for the genus Mycobacterium and for description of new slowly growing Mycobacterium species. Int J Syst Bacteriol 42, 315-323.

Luquin, M., Ausina, V., Calahorra, F. L., Belda, F., Barcelo, M. G., Celma, C. \& Prats, G. (1991). Evaluation of practical chromatographic procedures for identification of clinical isolates of mycobacteria. J Clin Microbiol 29, 120-130.

Lutz, B. (1992). Identification tests for mycobacteria. In Clinical Microbiology Procedures Handbook, pp. 3.12.1-3.12.27. Edited by H. D. Isenberg. Washington, DC: American Society for Microbiology.

Maidak, B. L., Larsen, N., McCaughey, M. J., Overbeek, R., Olsen, G. J., Fogel, K., Blandy, J. \& Woese, C. R. (1994). The Ribosomal Database Project. Nucleic Acids Res 22, 3485-3487.

Minnikin, D. E., Hutchinson, I. G., Caldicott, A. B. \& Goodfellow, M. (1980). Thin-layer chromatography of methanolysates of mycolic acid-containing bacteria. $J$ Chromatogr 188, 221-233.

Minnikin, D. E., Minnikin, S. M., Parlett, J. H. \& Goodfellow, M. (1985). Mycolic acid patterns of some rapidly-growing species of Mycobacterium. Zentbl Bakteriol Hyg A 259, 446-460.

Murray, R. G. E., Doetsch, R. N. \& Robinow, C. F. (1994). Determinative and cytological light microscopy. In Methods for General and Molecular Bacteriology, pp. 21-41. Edited by P. Gerhardt, R. G. E. Murray, W. A. Wood \& N. R. Krieg. Washington, DC: American Society for Microbiology.

Mylvaganam, S. \& Dennis, P. P. (1992). Sequence heterogeneity between the two genes encoding 16S rRNA from the halophilic archaebacterium Haloarcula marismortui. Genetics 130, $399-410$.

Ninet, B., Monod, M., Pawlowski, E. J., Metral, C., Rohner, P., Auckenthaler, R. \& Hirschel, B. (1996). Two different 16S rRNA genes in a mycobacterial strain. J Clin Microbiol 34, 2531-2536.

Peters, M., Mueller, C., Ruesch-Gerdes, S., Seidel, C., Göbel, U., Pohle, H. D. \& Ruf, B. (1995). Isolation of atypical mycobacteria from tap water in hospitals and homes: is this a possible source of disseminated MAC infection in AIDS patients? $J$ Infection 31, 39- 44 .

Rainey, F. A., Ward-Rainey, N. L., Janssen, P. H., Hippe, H. \& Stackebrandt, E. (1996). Clostridium paradoxum DSM $7308^{\mathrm{T}}$ contains multiple 16 rRNA genes with heterogeneous intervening sequences. Microbiology 142, 2087-2095.

Reznikov, M., Leggo, J. H. \& Dawson, D. J. (1971). Investigation by seroagglutination of strains of the Mycobacterium intracellulare-M. scrofulaceum group from house dusts and sputum in Southeastern Queensland. Am Rev Resp Dis 104, 951-953.

Saitou, N. \& Nei, M. (1987). The neighbor-joining method: a new method for reconstructing phylogenetic trees. Mol Biol Evol 4, 406-425.

Sneath, P. H. A. \& Sokal, R. R. (1973). Numerical Taxonomy: the Principles and Practice of Numerical Classification. San Francisco: Freeman.

Soini, H., Skurnik, M., Liippo, K., Tala, E. \& Viljanen, M. K. (1992). Detection and identification of mycobacteria by amplification of a segment of the gene coding for the 32-kilodalton protein. $J$ Clin Microbiol 30, 2025-2028.

Stackebrandt, E., Rainey, F. A. \& Ward-Rainey, N. L. (1997). Proposal for a new hierarchic classification system, Actinobacteria classis nov. Int J Syst Bacteriol 47, 479-491.

Tsukamura, M. \& Ichiyama, S. (1986). Numerical classification of rapidly growing nonphotochromogenic mycobacteria. Microbiol Immunol 30, 863-882.

Tsukamura, M., Mizuno, S., Murata, H., Nemoto, H. \& Yugi, H. (1974). A comparative study of mycobacteria from patient's room dust from sputa of tuberculous patients. Jpn J Microbiol 18, 271-277.

Tsukamura, M., Van der Meulen, H. J. \& Grabow, W. O. H. (1983). Numerical taxonomy of rapidly growing, scotochromogenic mycobacteria of the Mycobacterium parafortuitum complex: Mycobacterium austroafricanum sp. nov. and Mycobacterium diernhoferi sp. nov. nom. rev. Int J Syst Bacteriol 33, 460-469.

Vaneechoutte, M., de Beenhouwer, H., Claeys, G., Verschraegen, G., de Rouck, A., Paepe, N., Elaichouni, A. \& Portaels, F. (1993). Identification of Mycobacterium species by using amplified ribosomal DNA restriction analysis. $J$ Clin Microbiol 8, 2061-2065.

Wayne, L. G. \& Krasnow, I. (1966). Preparation of tuberculosis susceptibility testing mediums by impregnated discs. $\mathrm{Am} \mathrm{J}$ Pathol 45, 769-771. 